[Radiocarbon, Vol. 17, No. 3, 1975, P. 313-327]

\title{
UNIVERSITY OF ROME CARBON-14 DATES XIII
}

\author{
M ALESSIO, F BELLA, S IMPROTA
}

Istituto di Fisica, Università di Roma

\section{G BELLUOMINI, G CALDERONI, C CORTESI, G L MANELLI, and A VIGILANTE}

\author{
Istituto di Geochimica, Università di Roma
}

This list includes the second group of age measurements made from September 1972 to July 1974 using the benzene scintillation method. All archaeologic and geologic samples come from Italian territory. Chemical apparatus for benzene synthesis and the liquid scintillation spectrometer are unchanged (Alessio et al, 1970a, 1973). Charcoal and wood samples underwent standard pretreatment by boiling with 5 to $10 \% \mathrm{HCl}$; $\alpha$-labeled samples were given additional leaching with .2N NaOH. The counting rate of approx half the samples was corrected based on the ${ }^{13} \mathrm{C} /{ }^{12} \mathrm{C}$ ratio, mass-spectrometrically measured on $\mathrm{CO}_{2}$ obtained in combustion line set up after Broecker et al (1959), according to previously described procedure (Alessio et al, 1969).

As in dating with the $\mathrm{CO}_{2}$ proportional counter, the modern standard is the same wood grown near Rome from 1949 to 1953, the activity of which is repeatedly checked with $95 \%$ of the activity of NBS oxalic acid and measurements are found coincident within $1 \sigma$. Errors quoted are $1 \sigma$ statistical error. Ages were calculated using the Libby half-life of $5568 \pm$ $30 \mathrm{yr}$, with 1950 as the standard year of reference. Direct transformation of carbonate materials $\left(\mathrm{CaCO}_{3}\right)$ into carbide was also attempted, using the following reaction (Fontes, 1971):

$$
2 \mathrm{CaCO}_{3}+10 \mathrm{Li} \underset{\text { ca } 700^{\circ} \mathrm{C}}{\longrightarrow} 2 \mathrm{CaO}+4 \mathrm{Li}_{2} \mathrm{O}+\mathrm{Li}_{2} \mathrm{C}_{2}
$$

We operated as follows: finely pulverized carbonate exceeding stoichiometrically required quantity by $80 \%$ (Barker, 1953) was thoroughly mixed in the reactor bottom with metallic lithium pellets. At ca $700^{\circ} \mathrm{C}$ most $\mathrm{CO}_{2}$ from thermal decomposition of carbonate reacted almost immediately with melted lithium; reaction was completed and radon removed at ca $700^{\circ} \mathrm{C}$. Pressure inside the reactor was carefully controlled throughout the process (120 to $150 \mathrm{~min}$ ).

Calcium carbonates obtained from different materials in $\mathrm{CO}_{2}$ preparation and purification line for proportional counter (Alessio et al, 1970a), and already dated by this method, were used as check samples.

As shown in Table 1, yields, calculated as the ratio of quantity of acetylene $\left(L\right.$ at $P_{0} V_{o}$ ) from all carburization and hydrolysis reactions to theoretical acetylene quantity, are rather low, possibly due to some faults in experimental apparatus. Dates obtained ('Table 1) agree fairly well with corresponding ones measured with the $\mathrm{CO}_{2}$ proportional counter; in fact, only R-566 dates are unaccountably discordant. 


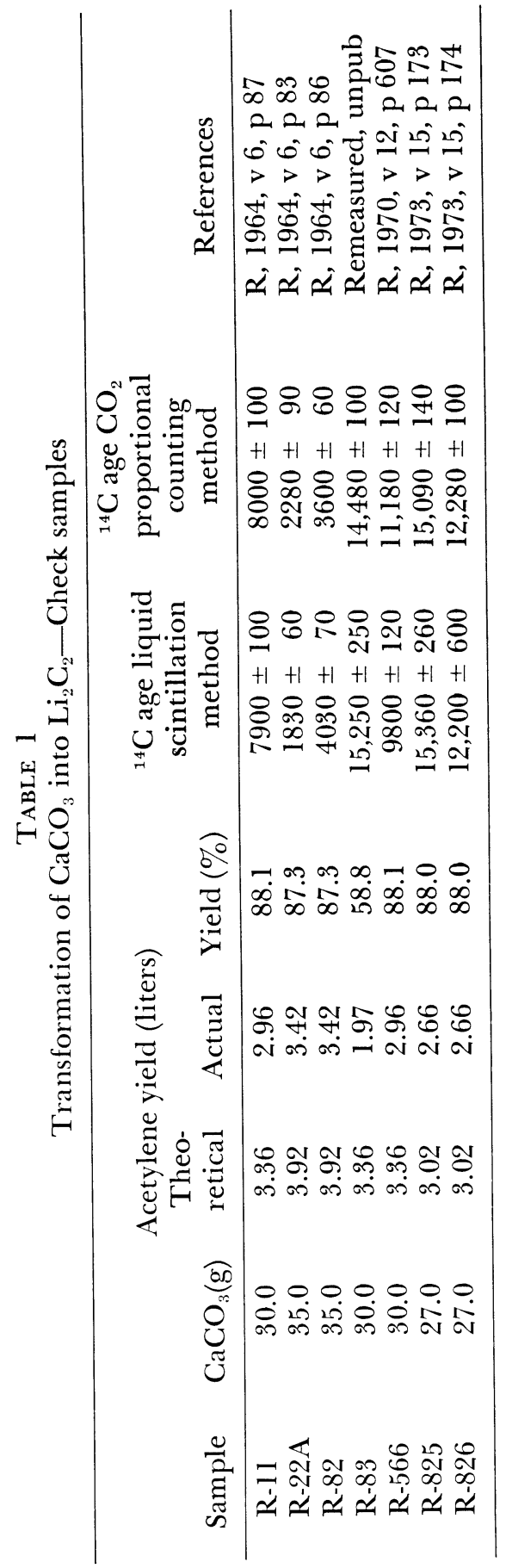


ACKNOWLEDGMENTS

We express our thanks to Consiglio Nazionale delle Ricerche for partial financial support.

\section{SAMPLE DESGRIPTIONS}

I. ARCHAEOLOGIC AND HISTORIC SAMPLES

\section{Massarosa series}

$$
\text { Italy }
$$

A small Etruscan perilacustrine settlement was discovered in 1966 in Massarosa reclamation area at $S$ Rocchino near Viareggio, prov Lucca, Tuscany (43 $\left.52^{\prime} 52^{\prime \prime} \mathrm{N}, 10^{\circ} 17^{\prime} 22^{\prime \prime} \mathrm{E}\right)$. Excavations carried out 196970 by M Cristofani, Sopr Antichità Etruria, Florence, uncovered some superimposed stamped earth floors of huts overlying archaeol sterile peat and surrounded by a double quadrangular palisade externally reinforced on $S$ side by a system of random horizontal trunks supported by wooden piles driven into peaty soil. Pottery datable to 7 th or early 6 th century BC was found both inside, embedded in hut bottoms, and outside, in peaty soil (Maetzke et al, 1970; Cristofani, 1974, 1975). Wood (Quercus ilex, Fraxinus orno, Coniferae) from wooden piles and palisade coll 1969 by M Cristofani and subm 1969 by G Maetzke, Sopr Antichità Etruria, Florence.

\section{R-688 $\alpha$. Massarosa 1}

$$
\begin{gathered}
2580 \pm 50 \\
630 \text { BC } \\
\delta^{13} C=-27.9 \% 0
\end{gathered}
$$

Wood, block of roots from Sq XLVIII-11, Layer T, Cut 4.

\section{R-689 $\alpha$. Massarosa 2}

$2110 \pm 50$ $160 \mathrm{BC}$

Darkened wood, fragment of wooden pile from Sq XLVIII-11, Layer T, Cut 4.

\section{R-690 $\alpha$. Massarosa 3} T, Cut 4.

Darkened wood, fragment of wooden pile from Sq XLVIII-11, Layer

\section{R-691 $\alpha$. Massarosa 4} T, Cut 4.

Darkened wood, fragment of wooden pile from Sq XLVIII-11, Layer

\section{R-692 $\alpha$. Massarosa 5}

Darkened wood, fragment of wooden pile from Sq XLVIII-11, Layer T, Cut 3. 


\section{R-693 $\alpha$. Massarosa 6}

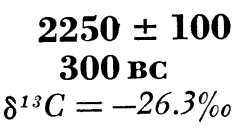

Darkened wood from wooden pile of NS palisade.

R-694 $\alpha$. Massarosa 7

$\mathbf{2 2 3 0} \pm \mathbf{5 0}$

280 BC

$\delta^{13} C=-26.7 \%$

Darkened wood from wooden pile of NS palisade, $\mathrm{E}$ side of huts.

\section{R-695 $\alpha$. Massarosa 8}

$2470 \pm 50$

Darkened wood from wooden pile of NS palisade.

520 BC

\section{R-696 $\alpha$. Massarosa 9}

$2280 \pm 50$

Darkened wood (Quercus ilex) from wooden pile of hut, E side.

General Comment: based on archaeol data, these dates must be considered too young; only R-688 $\alpha$ and $-695 \alpha$ ages agree.

\section{Lago di Mezzano series}

In 1972, 2 lake dwelling settlements were discovered at bottom of Mezzano little crater lake in caldera of Latera, Vulsini Mts volcanic region, Comm Valentano, prov Viterbo, Latium (42 $46^{\circ} 30^{\prime \prime} \mathrm{N}, 11^{\circ} 46^{\prime} 08^{\prime \prime}$ E) at $+452 \mathrm{~m}$, max water depth $36 \mathrm{~m}$. In 1973 an underwater archaeol exploration was made for Sopr Etruria Meridionale, by L Ferri-Ricchi, Comitato Ital Ricerche e Studi Subacquei, and M C Franco. Geologic investigations and a topographic and bathymetric survey were also made: ca 50 piles, diam 10 to $20 \mathrm{~cm}$, driven in to the bottom, were mapped and sampled. Abundant archaeol material was recovered, including some bronze objects and "impasto" pottery, namely domestic, consisting of $>50$ entire vases, one incised, the others plain or with plastic decoration, attributed to end of Middle and Late Bronze age, possibly up to its final phase (M C Franco, 1975). Wood from piles and planks subm 1973 by L Ferri-Ricchi and id by M Follieri and A Catullo, Ist Bot, Univ Rome. $5 \% \mathrm{HCl}$ pretreatment of darkened and impaired wood did not disclose $\mathrm{CO}_{3}--$; soluble organic fraction (fulvic acids) and abundant $\mathrm{Fe}^{++}$were detected; scarce or absent humic acids soluble in $.2 \mathrm{~N} \mathrm{NaOH}$.

\section{Mezzano I settlement}

NE side of lake near effluent Olpeta R, 20 to $30 \mathrm{~m}$ from shore, water depth 3 to $10 \mathrm{~m}$. Settlement comprises 2 units separated by apparently sterile zone and marked Mezzano I-A $\left(42^{\circ} 36^{\prime} 39^{\prime \prime} \mathrm{N}, 11^{\circ} 46^{\prime} 19^{\prime \prime} \mathrm{E}, \mathrm{U} \mathrm{T}\right.$ M 32-TQN-275217), and Mezzano I-B (42 $36^{\prime} 41^{\prime \prime} \mathrm{N}, 11^{\circ} 46^{\prime} 18^{\prime \prime} \mathrm{E}, \mathrm{U} \mathrm{T}$ M 32-TQN-275218). 
R.973 $\alpha$. Mezzano I-A, I

Wood (Quercus sp, deciduous group), fragments of pile ca $30 \mathrm{~m}$ from shore in bottom clayey sediment, water depth ca $7 \mathrm{~m}$, assoc with abundant archaeol finds.

\section{R-974 $\alpha$. Mezzano I-A, 2}

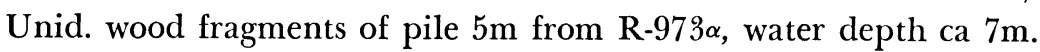

\section{R-975 $\alpha$. Mezzano I-A, 3}

$2760 \pm 50$

Wood (Quercus sp, deciduous group), fragments of pile ca $15 \mathrm{~m}$ from shore, water depth ca $5 \mathrm{~m}$.

\section{R-976 $\alpha$. Mezzano I-A, 4}

Unid. wood fragment of pile ca $2 \mathrm{~m}$ from R-975 , water depth ca $5 \mathrm{~m}$.

\section{R-984 $\alpha$. Mezzano I-A, 24A}

$3320 \pm 60$

1370 BC

Wood (Quercus sp, deciduous group) from pile, diam $14 \mathrm{~cm}$, just protruding from bottom ca $20 \mathrm{~cm}$ at mapped point $24 \mathrm{~A}$, water depth $7.60 \mathrm{~m}$.

\section{R-987. Mezzano I-A, 28A}

$$
\begin{gathered}
3200 \pm 50 \\
1250 \text { BC } \\
\delta^{13} C=-26.7 \% 0
\end{gathered}
$$

Wood (Alnus sp) from pile, diam ca $14 \mathrm{~cm}$, just protruding from bottom at $28 \mathrm{~A}$ mapped point, water depth $9 \mathrm{~m}$. Comment: test with $.2 \mathrm{~N}$ $\mathrm{NaOH}$ did not disclose humic acids.

R-988. Mezzano I-B, 30B

$$
\begin{array}{r}
\mathbf{2 6 8 0} \pm \mathbf{5 0} \\
\mathbf{7 3 0} \mathbf{B C} \\
\delta^{13} C=-25.7 \% \\
\mathbf{2 7 3 0} \pm \mathbf{5 0} \\
\mathbf{7 8 0 ~ B C} \\
\delta^{13} C=-25.7 \%
\end{array}
$$

R-988 $\alpha$. Mezzano I-B, 30B

Wood (Quercus sp, deciduous group) from pile sq sec, $9 \mathrm{~cm}$ side, coated with clayey matrix and evidence of industry just protruding from bottom at 30B mapped point, water depth $4 \mathrm{~m}$. Comment: 2 dates agree: scarce humic acids disclosed by .2N NaOH leaching (R-988 $\alpha$ ) seemed uncontaminating.

R-989. Mezzano I-B, 33B

$$
\begin{gathered}
2910 \pm 50 \\
960 \text { BC } \\
\delta^{13} \mathrm{C}=26.1 \%
\end{gathered}
$$

Wood (Alnus sp) from pile, diam $14 \mathrm{~cm}$, just protruding from bottom 
at $33 \mathrm{~B}$ mapped point, water depth $9 \mathrm{~m}$. Comment: test with $.2 \mathrm{~N} \mathrm{NaOH}$ did not disclose humic acids.

Mezzano II settlement

NE side of lake, $500 \mathrm{~m} \mathrm{~S}$ Mezzano I, 20 to $30 \mathrm{~m}$ from shore, water depth ca 6 to $12 \mathrm{~m}\left(42^{\circ} 36^{\prime} 25^{\prime \prime} \mathrm{N}, 11^{\circ} 46^{\prime} 17^{\prime \prime}\right.$ E, U T M 32-TQN-275213).

\section{R-985A $\alpha$. Mezzano II, 27a}

$2870 \pm 50$

Wood (Quercus sp, deciduous group) from 2 fragments of same plank, ca $2 \mathrm{~cm}$ thick, with charred side from bottom at $27 \mathrm{a}$ mapped point, water depth $9 \mathrm{~m}$, near R-986.

R-985B. Mezzano II, 27a

$\mathbf{2 8 4 0} \pm \mathbf{5 0}$

890 вC

$\delta^{13} C=-26.6 \%$

Wood from other 2 fragments of R-985A plank. Comment: test with $.2 \mathrm{~N} \mathrm{NaOH}$ did not disclose humic acids. 2 dates agree as expected.

R-986. Mezzano II, 27b

$$
\begin{gathered}
\mathbf{2 8 0 0} \pm \mathbf{5 0} \\
\mathbf{8 5 0} \text { BC } \\
\delta^{13} C=-27.5 \%
\end{gathered}
$$

Wood (Acer cf opalus Mill) from pile, diam $10 \mathrm{~cm}$, just protruding from bottom at $27 \mathrm{~b}$ mapped point, water depth $9 \mathrm{~m}$. Comment: test with $.2 \mathrm{~N} \mathrm{NaOH}$ did not disclose humic acids.

\section{R-990. Mezzano II, 34}

$$
\begin{gathered}
3000 \pm 50 \\
1050 \text { BC } \\
\delta^{13} C=-26.8 \% o
\end{gathered}
$$

Wood (Acer cf platanoides L) from pile, diam $13 \mathrm{~cm}$, just protruding from bottom at mapped point 34 , water depth $9.30 \mathrm{~m}$. Comment: test with $.2 \mathrm{~N} \mathrm{NaOH}$ did not disclose humic acids.

\section{R.991. Mezzano II, 35a}

$$
\begin{gathered}
2970 \pm 60 \\
1020 \text { BC } \\
\delta^{13} C=-26.6 \%
\end{gathered}
$$

Wood (Acer cf platanoides L) from pile, diam $12 \mathrm{~cm}$, just protruding from bottom at $35 \mathrm{a}$ mapped point, water depth $9.30 \mathrm{~m}$. Comment: test with $.2 \mathrm{~N} \mathrm{NaOH}$ did not disclose humic acids. 35 a to $35 \mathrm{e}$ samples are close together.

\section{R-992. Mezzano II, 35b}

$$
\begin{gathered}
\mathbf{2 7 6 0} \pm \mathbf{6 0} \\
\mathbf{8 1 0 ~ B C} \\
\delta^{13} C=-26.1 \% \\
\mathbf{2 8 4 0} \pm \mathbf{5 0} \\
\mathbf{8 9 0} \mathbf{B C} \\
\delta^{13} C=-26.0 \%
\end{gathered}
$$$$
\text { R-992 } \alpha \text {. Mezzano II, 35b }
$$

Wood (Quercus sp, deciduous group) from pile, diam $12 \mathrm{~cm}$, just protruding from bottom at $35 \mathrm{~b}$ mapped point, water depth $9.30 \mathrm{~m}$. Comment: 
2 dates agree; scarce humic acids disclosed by $\mathrm{NaOH}$ leaching (R-992 $\alpha$ ) seemed uncontaminating.

\section{R-993. Mezzano II, 35c}

Wood (Acer cf platanoides $\mathrm{L}$ ) from pile, diam $15 \mathrm{~cm}$, with evidence of industry just protruding from bottom at 35c mapped point, water depth $9.30 \mathrm{~m}$. Comment: test with $.2 \mathrm{~N} \mathrm{NaOH}$ did not disclose humic acids.

\section{R-994A. Mezzano II, 35d}

$$
\begin{gathered}
2900 \pm 50 \\
950 \text { BC } \\
\delta^{13} C=-27.5 \% o
\end{gathered}
$$

Wood (Fagus silvatica L) fragment of plank, $3 \mathrm{~cm}$ thick, with partially charred side from bottom at $35 \mathrm{~d}$ mapped point, water depth $9.30 \mathrm{~m}$. Comment: test with $.2 \mathrm{~N} \mathrm{NaOH}$ did not disclose humic acids.

\section{R-994B. Mezzano II, 35d}

$$
\begin{gathered}
2970 \pm 60 \\
1020 \text { BC } \\
\delta^{13} C=-27.1 \% o
\end{gathered}
$$

Charcoal from charred portion of R-994A plank. Comment: 2 dates agree as expected.

\section{R-995 $\alpha$. Mezzano II, 35e}

$$
\begin{gathered}
2920 \pm 50 \\
970 \text { BC } \\
\delta^{13} C=-26.9 \% o
\end{gathered}
$$

Wood (Quercus sp, deciduous group) fragment of plank, $3 \mathrm{~cm}$ thick, with partially charred side from bottom at $35 \mathrm{e}$ mapped point, water depth $9.30 \mathrm{~m}$.

General Comment: 14 of 16 dates from Mezzano agree with Late Bronze age, 10th to 13th centuries BC. Specifically, 6 of 8 dates for Mezzano II are from 10th to 13th centuries BC; those of Mezzano I-A, except a younger one (R-975), are between 12th and 14th centuries BC; Mezzano I-B, not sufficiently explored and dated (only 2 dates), appears somewhat younger, 8 th to 10 th centuries BC, the age of R-988 pile, from minimum water depth $4 \mathrm{~m}$, is the youngest.

The discovery, even in Bolsena and Bracciano crater lakes, of prehistoric settlements previous to 7 th century BC, now submerged $>5 \mathrm{~m}$, along with geologic, geomorphologic, archaeol, and historical data relevant to other lakes in Central Italy, eg, Trasimeno, Vico, Martignano, Monterosi, Albano, Nemi, and Fucino Lakes, reveal similar fluctuations in water level, possibly contemporaneous in the last $4000 \mathrm{yr}$. A common cause, according to L Ferri-Ricchi, might be assoc with climatic changes, namely cyclic alternations of rainy and dry periods (Ferri-Ricchi, 1975a,b, and oral commun). ${ }^{14} \mathrm{C}$ dates contribute to chronology of these events. See also Gran Carro, Lago di Bolsena and Lago di Martignano, General Comment, below. 


\section{R-859 $\alpha$. Gran Carro, Lago di Bolsena}

Darkened wood (Quercus sp, deciduous group) id by M Follieri and R D'Alessandro, Ist Bot, Univ Rome, from wooden pile driven in and just protruding from bottom sediments of Bolsena crater lake, water depth ca 5m, near E shore at Gran Carro, prov Viterbo, Latium $\left(42^{\circ} 35^{\prime}\right.$ $\left.23^{\prime \prime} \mathrm{N}, 11^{\circ} 59^{\prime} 44^{\prime \prime} \mathrm{E}\right)$. Coll and subm by A Fioravanti and E Loret, Gruppi Archeol Italia, for Sopr Etruria Meridionale, Rome. Comment: this lake dwelling settlement yielded abundant pottery of Villanovan culture (Colonna, 1965, 1967) id through underwater explorations (Fioravanti, $1963,1965,1967-68,1969) .{ }^{14} \mathrm{C}$ age agrees with archaeol data. See also Lago di Mezzano General Comment, above.

\section{R-915. Monti del Forno, Montelibretti}

$1350 \pm 150$

Charcoal from hearth in deposit obstructing surface entrance and filling along ca $10 \mathrm{~m}$ a tunnel excavated in tuff found during foundation work at Monti del Forno, $29.3 \mathrm{~km}$ along state rd No. 4 Salaria, Comm Montelibretti, prov Rome $\left(42^{\circ} 06^{\prime} 27^{\prime \prime} \mathrm{N}, 12^{\circ} 38^{\prime} 28^{\prime \prime} \mathrm{E}\right)$ at $+45.5 \mathrm{~m}$. Coll 1972 by R Caciagli and subm 1972 by G Donato, both of Servizio Sci Sussidiarie Archeol C N R, Rome. Comment: tunnel, $70 \mathrm{~cm}$ wide and $180 \mathrm{~cm}$ high, is well preserved and practicable; a stretch of ca $130 \mathrm{~m}$ roughly explored is downhill for ca $10 \mathrm{~m}$ below surface. So far there is no data to determine excavation time and early use of tunnel which is in an area rich in archaeol remains and tunnels of various epochs under study. Probably ${ }^{14} \mathrm{C}$ age dates its re-use in the Middle ages, possibly as a sheperd shelter.

\section{GEOLOGIC SAMPLES}

Italy

\section{Grange La Coche series}

Peat and wood from Grange La Coche Holocene peat bog, $1.3 \mathrm{~km} \mathrm{E}$ Clavière, Alta Val di Susa, Alpi Cozie, prov Turin, Piedmont $\left(44^{\circ} 56^{\prime}\right.$ 06" N, 6 46' 21" E; U T M 32-TLO-23887853), at +1924m. Coll 1968 and subm 1969 and 1972 by G Charrier, Ist Giacimenti Min, Politec Turin. Profile, ca $1 \mathrm{~m}$ thick, includes: surface soil; Cyperaceae peat remains; darker and more compact peat crossed by abundant root remains in situ of Larix decidua Mill (id by G Charrier, written commun, 1972) found elsewhere even below peat in thin silty layer, transition to underlying moraine. La Coche peat bog belongs to series of Lowmoor bogs "sagnes" type formed during Holocene on a recent moraine system.

\section{R-621A. Grange La Coche 1}




\section{R-621 $\alpha$. Grange La Coche 1}

Light and soft upper peat, mainly Cyperaceae remains $5 \mathrm{~cm}$ below surface. Comment: R-621 was given no pretreatment; R-621 $\alpha$ underwent acid-alkaline pretreatment. Two dates must be considered as minimum since upper peat was pervaded by several roots of present plants removed by hand during preparation.

\section{R-620A. Grange La Coche 2}

Dark and compact lower peat from $100 \mathrm{~cm}$ depth near base of peat bog. Comment: R-620 $\alpha$ was given acid-alkaline standard pretreatment; date is reliable. R-620A was given no pretreatment: date shows strong contamination by younger humic materials.

\section{R-914aA. Grange La Coche 3a}

$4475 \pm 95$ 2525 BC

\section{R-914a. Grange La Coche 3a}

$3310 \pm 100$

Well preserved wood, large fragment of root (Larix decidua Mill) in situ at base of peat bog. See R-914b comment.

\section{R-914b. Grange La Coche $3 b$}

Well preserved wood, other fragments of roots (Larix decidua Mill) in situ at base of peat bog. Comment: R-914a/b are reliable ages of roots; samples were pretreated with $5 \% \mathrm{HCl}$ only because test with $.2 \mathrm{~N} \mathrm{NaOH}$ did not disclose humic acids. R-914aA was given no pretreatment: age is not reliable as sample appears strongly contaminated by humic materials, mainly fulvic acids soluble in $5 \% \mathrm{HCl}$, from overlying older peat.

General Comment: R-621A/ $\alpha$ dates belong to uppermost level of upper peat, -5 to $-50 \mathrm{~cm}$, which began forming only after end of cold phase in Early Sub-Atlantic, also agrees with pollen analysis, showing a strong decrease of Abies curve from $-50 \mathrm{~cm}$ upwards. R- $620 \alpha$ dates beginning of peat formation in intermorainal basin in Late Atlantic; pollen analysis confirms attribution of lower peat, up to $-50 \mathrm{~cm}$ level, to Atlantic/subBoreal transition and to Sub-Boreal. R-914a/b, Larix wood, dated from 1260 to 1530 BC, belongs to warmer phase in Sub-Boreal which caused a rise of upper limit of forest line and a vast retreat of alpine glaciers, as proved in many places in the Alps.

Agreeing with pollen analytic data (Charrier and Peretti, 1974), ${ }^{14} \mathrm{C}$ ages set Holocene peat bogs in Val di Susa in chronologic sequence from Pre-Boreal, Villar Dora (R-158: R, 1968, v 10, p 359), through Boreal and Boreal/Atlantic transition, Novaretto (R-52: R, 1964, v 6, p 86), up to Atlantic/Sub-Boreal transition, to Sub-Boreal and Sub-Atlantic, Grange La Coche (above) which appears somewhat older than Colle del Sestrière 
peat bog in nearby Val Chisone, dated between late Sub-Boreal and early Sub-Atlantic (R-53: R, 1964, v 6, p 86; R-617A/ $\alpha$ : R, 1970, v 12, p 610).

\section{Rovagnate series}

Dark peaty clay with abundant vegetable remains at $150 \mathrm{~cm}$ depth from surface soil, at top of lacustrine sediments of Rovagnate, at Fornace, Comm Castello Di Brianza, prov Como, Lombardy (45 $44^{\prime} 54^{\prime \prime} \mathrm{N}, 09^{\circ} 21^{\prime}$ 14" E). Coll and subm by G Orombelli, Ist Geol, Univ Milano. $180 \mathrm{~cm} \mathrm{sec}$ reveals deposits of final phases and extinction of Rovagnate Lake, an intermorainal basin dammed by ice-contact delta. For descriptions of stratigraphic sec, see: Riva (1954, 1957); Gnaccolini and Orombelli (1971); Orombelli (1975).

\section{R-837. Rovagnate}

Dark peaty clay from top of lacustrine sediment, $-150 \mathrm{~cm}$ depth from surface soil.

\section{R-837a. Rovagnate a}

Vegetable remains, mainly small darkened wood fragments, from R-837 peaty clay. Comment: wood fragments were carefully separated by sieving.

General Comment: R-837, the more reliable age, places last phase of Rovagnate Lake in postglacial climatic optimum, Hypsithermal, and gives maximum age for overlying sediments and soil, the latter can be correlated to other neighboring soils. ${ }^{14} \mathrm{C}$ date agrees well with geologic data for region (Orombelli, 1975).

\section{R-801 $\alpha$. Pontida}

$17,700 \pm 360$

Darkened vegetable remains, mainly twigs, leaves and seeds, from thin layer of fine sand embedded in laminated silty clays of Pontida lacustrine sediments ca $20 \mathrm{~m}$ thick, from $10 \mathrm{~m}$ depth from surface soil in sec of quarry Fornace Magnetti, Comm Cisano Bergamasco, prov Bergamo, Lombardy ( $\left.45^{\circ} 44^{\prime} 08^{\prime \prime} \mathrm{N}, 09^{\circ} 29^{\prime} 27^{\prime \prime} \mathrm{E}\right)$. Coll and subm 1970 by G Orombelli. Comment: Pontida lacustrine sediments were lain in a frontal intermorainal basin formed by piedmont glacial lobe of Adda di Lecco $\mathrm{R}$ in S Martino Valley (Desio, 1928; Riva, 1957; Venzo, 1948; Gabert, 1962). ${ }^{14} \mathrm{C}$ age, 1st available for Würm deposits in Lombardy, dates a phase of lacustrine sediments and represents minimum age for moraine damming the basin. Date is important for chronology of last glaciation S of Alps (Orombelli, 1975).

\section{Pianico series}

Three fragments of warped and lignitous trunks from glacial and lacustrine sediments of Pianico, right bank of Borlezza Stream, Comms

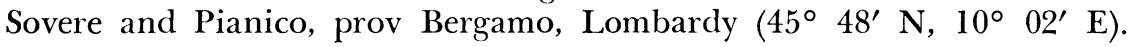
Coll and subm 1970 by $\mathrm{G}$ Orombelli. 
R-804 $\alpha$. Pianico 1

Heavily darkened wood, fragment of apparently lignitous trunk longitudinally flattened, from ca $8 \mathrm{~m}$ depth from surface in glacial basal layer overlying lacustrine sediments of Pianico, right bank of Borlezza Stream ( $\left.45^{\circ} 48^{\prime} 57^{\prime \prime} \mathrm{N}, 10^{\circ} 01^{\prime} 53^{\prime \prime} \mathrm{E}\right)$. Comment: $5 \%$ HCl pretreatment detects scarce carbonate and abundant $\mathrm{Fe}^{++}$, probably ferrous humate. R-804, quite similar in aspect and impairment to R-805 and -806 wood, must be considered as reworked by glacier and belonging to underlying lacustrine sediments.

R-805 $\alpha$. Pianico 2

Heavily darkened wood, fragment of apparently lignitous and longitudinally flattened trunk, from ca $6 \mathrm{~m}$ depth from soil surface in lacustrine sediments of Pianico, right bank of Borlezza Stream $\left(45^{\circ} 48^{\prime}\right.$ $\left.53^{\prime \prime} \mathrm{N}, 10^{\circ} 02^{\prime} 00^{\prime \prime} \mathrm{E}\right)$. Comment: $5 \% \mathrm{HCl}$ pretreatment detects scarce carbonate and abundant $\mathrm{Fe}^{++}$, probably ferrous humate.

\section{R-806. Pianico $3 \quad>43,000$ \\ R-806 $\alpha$. Pianico 3

Heavily darkened wood, fragment of apparently lignitous and longitudinally flattened trunk, from ca $15 \mathrm{~m}$ depth from soil surface in lacustrine sediments of Pianico ca $100 \mathrm{~m}$ E from R-805 $\alpha$, right bank of Borlezza Stream $\left(45^{\circ} 48^{\prime} 48^{\prime \prime} \mathrm{N}, 10^{\circ} 02^{\prime} 07^{\prime \prime} \mathrm{E}\right)$. Comment: $5 \%$ HCl pretreatment detects scarce carbonate and abundant $\mathrm{Fe}^{++}$, probably ferrous humate.

General Comment: lacustrine sediments of Pianico, mainly fossiliferous marly and clayey rythmites with abundant vegetable remains, and deltaic sands and gravels up to $70 \mathrm{~m}$ thick, with Würm glacial deposits on top, constitute a typical formation attributed to Riss-Würm interglacial, based on paleontologic, stratigraphic, and geomorphologic data (Venzo, 1955; Lona \& Venzo, 1957; Casati, 1968). ${ }^{14} \mathrm{C}$ date is necessary, as a Main Würm interstadial age is also possible, as it is for other alpine glacial formations once attributed to the same interglacial which turned out to be datable by ${ }^{14} \mathrm{C}$. R-804, $-805,-806$ minimum ages refute last assumption for Pianico formation and support traditional attribution (Orombelli, 1975).

\section{Trentino Lakes}

Systematic underwater explorations sponsored by Mus Tridentino Sci Nat, Trento, are revealing trunks of submerged forests at bottom of several lakes in Trentino. Measurements may date formation of lake basins, essential for palaeogeography of region. Wood id by M Follieri and R D'Alessandro, Ist Bot, Univ Roma.

\section{Lago di Tenno series}

Well preserved wood from trunks in situ at bottom of Tenno Lake, $4.5 \mathrm{~km} \mathrm{~N}$ Tenno, prov Trento, Trentino $\left(45^{\circ} 56^{\prime} \mathrm{N}, 10^{\circ} 49^{\prime} \mathrm{E}\right)$ at $+570 \mathrm{~m}$. Lake 3 in "Catasto laghi del Trentino" (Tomasi, 1962). Coll 1970 by Gruppo Sommozzatori Riva Del Garda and subm by B Bagolini and G Tomasi, Mus Tridentino Sci Nat, Trento. 
R-1026. Lago di Tenno 10

$\mathbf{9 4 0} \pm 50$
AD 1010
$\delta^{13} C=-26.9 \%$ o

Well preserved wood (Acer sp) from Trunk 10 in situ in bottom sediments, water depth $21 \mathrm{~m}$.

\section{R-1027. Lago di Tenno 39}

\section{AD 1180}

$\mathbf{7 7 0} \pm \mathbf{5 0}$

$\delta^{13} \mathrm{C}=-28.1 \%$

Well preserved wood (Fagus silvatica L) from Trunk 39 in situ in bottom sediments, water depth $33 \mathrm{~m}$.

General Comment: like R-793, -784, -795 trunks previously dated (R, 1973 , v 15, p 385), and all id as Fagus silvatica L, R-1026 and -1027 belong to submerged forest covering ca $1 / 5$ lake bottom on $\mathrm{W}$ side where $>70$ trees were mapped by Mus. ${ }^{14} \mathrm{C}$ dates, agreeing with previous ones, confirm once more traditional belief that Tenno Lake basin was formed by a landslide ca AD 1400 (Tomasi, 1962, 1963, 1974).

\section{R-1023 $\alpha$. Lago di Canzolino}

$$
370 \pm 60
$$

\section{AD 1580}

$\delta^{13} C=-25.9 \%$

Wood (Castanea sativa Mill) from outer part of large trunk, diam ca $85 \mathrm{~cm}$, found in situ, $11 \mathrm{~m}$ water depth and $28 \mathrm{~m}$ from $\mathrm{W}$ shore, at bottom of Canzolino Lake, ca $3 \mathrm{~km}$ NW Pergine Valsugana, prov Trento, Trentino $\left(46^{\circ} 05^{\prime} 00^{\prime \prime} \mathrm{N}, 11^{\circ} 13^{\prime} 33^{\prime \prime} \mathrm{E}\right)$ at $+540 \mathrm{~m}$. Lake 240 in "Catasto laghi del trentino" (Tomasi, 1962). Coll 1972 by M Cont, Pioneer Sub Gruppo Ricerche, Trento, and subm 1972 by M Bagolini and G Tomasi. Comment: several large trunks in situ belonging to submerged forest were found in $\mathrm{W}$ area of lake where a large landslide, identifiable by blocks up to $3 \mathrm{~m}$ in size, may have caused a sudden recent rise of water level. ${ }^{14} \mathrm{C}$ date explains present size of pre-existent basin. Area: 6.2 ha, max water depth: 15m (Tomasi, 1962, 1963, 1974). Corrected ${ }^{14} \mathrm{C}$ date (Ralph, Michael, \& Ham, 1973) from AD 1430 to 1520-1610.

\section{R-1024 $\alpha$. Lago di Cei}

$$
670 \pm 50
$$

\section{AD 1280}

$$
\delta^{13} C=-27.8 \% \text { o }
$$

Lightly darkened wood (Fagus silvatica $L$ ) from large trunk in situ, ca $7 \mathrm{~m}$ water depth and $50 \mathrm{~m}$ from $\mathrm{N}$ shore, in Cei Lake, ca $7 \mathrm{~km} \mathrm{~N}$ Rovereto, prov Trento, Trentino $\left(45^{\circ} 57^{\prime} 00^{\prime \prime} \mathrm{N}, 11^{\circ} 01^{\prime} 08^{\prime \prime} \mathrm{E}\right)$ at $+912 \mathrm{~m}$. Lake 185 in "Catasto laghi del Trentino" (Tomasi, 1962). Coll 1972 by M Cont and subm 1972 by M Bagolini and G Tomasi. Comment: some large trunks in situ were discovered in $\mathrm{N}$ deepest zone of lake, 5 to $7 \mathrm{~m}$ water depth, belonging to forest covering valley bottom before a landslide formed little barrier-lake. Area: 3.9ha, max water depth: 10m (Tomasi, 1962, 1963, 1974). Single ${ }^{14} \mathrm{C}$ age roughly dates event. 


\section{R-1025 $\alpha$. Lago di Lavarone}

Deeply darkened wood (Fagus silvatica L) from trunk in situ, 12.5 water depth and $70 \mathrm{~m}$ from $\mathrm{S}$ shore, at bottom of Lavarone Karst Lake, prov Trento, Trentino (45 $\left.56^{\circ} 10^{\prime \prime} \mathrm{N}, 11^{\circ} 15^{\prime} 08^{\prime \prime} \mathrm{E}\right)$ at $+1114 \mathrm{~m}$. Lake 244 in "Catasto laghi del Trentino" (Tomasi, 1962). Coll by M Cont 1972 and subm 1972 by B Bagolini and G Tomasi. Comment: ca 15 large trunks in situ of submerged forest were mapped from 3 to $17 \mathrm{~m}$ water depth on bottom of Lavarone Lake. Area: 5.4ha, max water depth: $17 \mathrm{~m}$. Forest covered doline bottom, until soil impermeability formed present lacustrine basin (Tomasi, 1962, 1963, 1974). Single ${ }^{14} \mathrm{C}$ age roughly dates event.

\section{Lago di Martignano series}

1971-73 underwater explorations made by L Ferri-Ricchi and E Loret, Gruppo Archeol Subacqueo Lazio, uncovered many well preserved large trunks in situ of perimetral submerged forest, 8 to $13 \mathrm{~m}$ water depth, in Martignano crater Lake, Sabatini Mts volcanic region, ca $2 \mathrm{~km} \mathrm{E} \mathrm{Brac-}$ ciano Lake, prov Rome (42 $06^{\prime} 40^{\prime \prime} \mathrm{N}, 12^{\circ} 18^{\prime} 18^{\prime \prime} \mathrm{E}$; U T M 33-TTG$774659)$ at $+207 \mathrm{~m}$, max water depth: ca $60 \mathrm{~m}$. Some trunks still in growth position protruded up to $5 \mathrm{~m}$ from bottom, others, up to $10 \mathrm{~m}$ height, were in subhorizontal position with roots still fixed in bottom sediments; several scattered trunks were in water as deep as $17 \mathrm{~m}$ (Ferri-Ricchi, 1972). Wood coll and subm 1972-73 by L Ferri-Ricchi and V Fornaseri; id by M Follieri.

\section{R-905 $\alpha$. Martignano 1}

$$
1600 \pm 80
$$

Wood (Quercus sp, deciduous group) from trunk in situ ca $20 \mathrm{~m}$ from W shore, water depth $12 \mathrm{~m}$.

\section{R-906A. Martignano 2}

$$
1450 \pm 80
$$

R-906. Martignano 2

\section{R-906 $\alpha$. Martignano 2}

Wood (Quercus sp, deciduous group) from trunk in situ ca $20 \mathrm{~m}$ from W shore, water depth $11 \mathrm{~m}$. Comment: R-906A was given no pretreatment; R-906 only $5 \%$ HCl pretreatment, R-906 $\alpha$ was given additional leaching with $.2 \mathrm{~N} \mathrm{NaOH}: 3$ dates agree.

\section{R-907A. Martignano 3}

$$
\begin{aligned}
1420 & \pm 80 \\
\text { AD } 530 & \\
1280 & \pm 80 \\
\text { AD } 670 &
\end{aligned}
$$$$
\text { R-907. Martignano } 3
$$ 
R-907 $\alpha$. Martignano 3

$1390 \pm 80$

Wood (Quercus sp, deciduous group) from trunk in situ ca $20 \mathrm{~m}$ from W shore, water depth $13 \mathrm{~m}$. Comment: see R-906 Comment above.

\section{R-979 $\alpha$. Martignano 4}

$1370 \pm 50$

AD 580

$\delta^{13} C=-23.6 \%$

Wood (Quercus sp, deciduous group) from trunk in situ ca $20 \mathrm{~m}$ from W shore, water depth $10 \mathrm{~m}$.

\section{R-980. Martignano 5}

$1440 \pm 50$

Wood (Quercus sp, deciduous group) from trunk in situ ca $20 \mathrm{~m}$ from W shore, water depth $12 \mathrm{~m}$. Comment: test with $.2 \mathrm{~N} \mathrm{NaOH}$ did not disclose humic acids.

General Comment: ${ }^{14} \mathrm{C}$ ages of submerged trunks, $3 \mathrm{rd}$ to 6 th centuries $\mathrm{AD}$, date ancient water level ca $20 \mathrm{~m}$ below present, controlled by an artificial effluent built last century. Another inlet of Roman effluent, built by Emperor Augustus 2 BC to supply Alseatinum aqueduct, was found in 1973 on $S$ side of crater wall, $8 \mathrm{~m}$ above present lake level; this, along with geomorphologic, geoarchaeol, and historic data, suggests ${ }^{14} \mathrm{C}$ dated oscillation of lake $>30 \mathrm{~m}$. Climatic change probably caused decrease in level, as for similar contemporaneous drops in lakes in Central Italy (Ferri-Ricchi, 1975a,b, oral commun). See also Lago di Mezzano series, General Comment, above.

REFERENCES

Alessio, M, Bella, F, and Cortesi, C, 1964, University of Rome carbon-14 dates II: Radiocarbon, v 6, p 77-90

Alessio, M, Bella, F, Cortesi, C, and Graziadei, B, 1968, University of Rome carbon-14 dates VI: Radiocarbon, v 10, p 350-364.

Alessio, M, Bella, F, Cortesi, C, and Turi, B, 1969, University of Rome carbon-14 dates VII: Radiocarbon, v 11, p 482-498.

Alessio, M et al, 1970a, Report on the equipment and activities of the Rome University's carbon-14 dating laboratory: Quaternaria, v 13, p 357-376. 616. 1970b, University of Rome carbon-14 dates VIII: Radiocarbon, v 12, p 599

1973, University of Rome carbon-14 dates XI: Radiocarbon, v 15, p 382-387.

Barker, Harold, 1953, Radiocarbon dating: large-scale preparation of acetylene from organic material: Nature, v 172, p 631-632.

Broecker, W S, Tucek, C S, and Olson, E A, 1959, Radiocarbon analysis of oceanic $\mathrm{CO}_{2}$ : Internatl Jour appl Radiation and Isotopes, v 7, p 1-18.

Casati, P, 1968, Alcune osservazioni sul bacino lacustre pleistocenico di Pianico (Lombardia): Ist Lombardo Sci Lettere Rend Sci, v A102, p 575-595.

Charrier, G, and Peretti, L, 1974, Applicazione dell'analisi palinologica e della datazione radiometrica $\mathrm{C}$ - $14 \mathrm{di}$ depositi torbosi intermorenici allo studio del clima e dell'ambiente naturale durante il Quaternario superiore nella regione alpina piemontese: Internatl Glaciol Soc, III Colloquio Sez Alpi Occidentali, Courmayeur,
6-8 Sept 1974, in press.

Colonna, G, 1965, Giacimento archeologico subacqueo in località Gran Carro: Min Pub Istruzione Boll Arte, v 50, no. 1-2, p 106.

1967, L'Etruria Meridionale interna dal Villanoviano alle tombe rupestri: Studi Etruschi, v 35, p 3-30.

Cristofani, M, 1974, A proposito della via dell'Arno, in: Aspetti e problemi dell'Etruria interna: VIII Convegno Studi Etruschi e Italici Atti, Firenze, p 67-69. 
Cristofani, M, 1975, Osservazioni preliminari sull-insediamento etrusco di Massarosa (Lucca): Archaeologica, studi in onore di A Neppi Modona Firenze, in press.

Desio, A, 1928, Su alcuni depositi lacustri singlaciali della Lombardia: Natura, v 19, p 158-166.

Ferri-Ricchi, L, 1972, La foresta pietrificata: Mondo Sommerso, v 14, no. 5, p 114-115. 1975a, Immersione nella preistoria: Mondo Sommerso, v 17, no. 1, p 20-30.

$1975 \mathrm{~b}$, Ricerca e rinvenimento di testimonianze geoarcheologiche nei laghi craterici del Lazio a dimostrazione di variazioni climatiche avvenute in epoca storica e preistorica: I Symposium Com Italiano Ricerche e Studi Subacquei Atti, Rome, Oct 1974, ms in preparation.

Fioravanti, A, 1963, Contributo alla carta archeologica del lago di Bolsena: Studi Etruschi, v 31, p 425-433.

1965, La Pompei del lago: Mondo Sommerso, v 7, no. 11, p 1222-1231.

1967, 1968, Un village il y a 3000 ans dans le lac de Bolsena: Aquatica, v 24, p 33-36; v 25, p 24-32.

1969, Il ritrovamento delle palafitte sotto le acque del lago di Bolsena: Enc Sci e Tecnica Mondadori, Ann 1969, p 266-267.

Fontes, J Ch, 1971, Un ensemble destiné à la mesure de l'activité du radiocarbone naturel par scintillation liquide: Rev Géog Phis et Géol Dynamique, v 13, p 67-86.

Franco, M C, 1975, Campagna di ricognizione preliminare subacquea con il recupero di materiale affiorante nel lago di Mezzano, Valentano (Viterbo), in: Catalogo della mostra nel Museo di Villa Giulia, in press.

Gabert, P, 1962, Les plaines occidentales du Pô et leur piedmonts (Piémont, Lombardie occidentale et centrale), étude morphologique: Louis Jean (ed), Gap.

Gnaccolini, M and Orombelli, G, 1971, Orientazione dei ciottoli in un delta lacustre pleistocenico della Brianza: Riv Italiana Paleontol Strat, v 77, p 411-424.

Lona, F and Venzo, S, 1957, La station interglaciaire de Pianico-Sellere, in: Guide itinéraire de la onzième excursion phytogeographique internatl, Alpes Orientales, 1956, p 39-46.

Maetzke, G, Fornaciari, G, and Mencarini, G, 1970, Massarosa (Lucca). Insediamento palafitticolo in località S Rocchino: Accad Naz Lincei Atti-Notizie degli scavi di Antichità, s 8, v 24, p 149-162.

Orombelli, G, 1975, Alcune date ${ }^{14} \mathrm{C}$ per il Quaternario lombardo: Studi Trentini Sci Nat, in press.

Ralph, E K, Michael, H N, and Ham, M C, 1973, Radiocarbon dates and reality: Masca newsletter, $v$ 9, p 1-20.

Riva, A, 1954, Il "glaciale" della Valle di Rovagnate: Soc Italiana Sci Nat Atti, v 93, p $221-234$.

1957, Gli anfiteatri morenici a sud del Lario e le pianure diluviali tra Adda e Olona: Ist Geol Univ Pavia Atti, v 7, p 1-93.

Tomasi, G, 1962, Origine, distribuzione, catasto e bibliografia dei laghi del Trentino: Studi Trentini Sci Nat, v 39, p 1-355.

1963, I laghi del Trentino: Manfrini ed, Rovereto. 79 .

Venzo, S, 1948, Rilevamento geomorfologico dell'apparato morenico dell'Adda di Lecco: Soc Italiana Sci Nat Atti, v 87, p 79-140.

1955 , Le attuali conoscenze sul Pleistocene lombardo con particolare riguardo al Bergamasco: Soc Italiana Sci Nat Atti, v 94, p 155-200. 